\title{
'They worship in our churches' - An opportunity for the church to intervene in order to diminish the corruption that is hindering service delivery in South Africa?
}

\begin{abstract}
Authors:
Benito Khotseng ${ }^{1}$

A. Roger Tucker ${ }^{1}$

Affiliations:

${ }^{1}$ Department of Practical

Theology, University of the

Free State, South Africa

Note:

Rev. Dr A. Roger Tucker is assistant research fellow at the Faculty of Theology, University of the Free State, Bloemfontein, South Africa. This article was initially a paper delivered at the annual meeting of the Society for Practical Theology in Potchefstroom, 23-25 January 2013. The theme of the conference: 'Practical theology and service delivery.' This article is published in the Section Practical Theology of the Society for Practical Theology in South Africa.
\end{abstract}

Correspondence to: Roger Tucker

Email:

roger@tuckerza.com

Postal address:

PO Box 28296, Danhof 9310

South Africa

\section{Dates:}

Received: 31 Jan. 2013

Accepted: 30 May 2013

Published: 30 Aug. 2013

How to cite this article: Khotseng, B. \& Tucker, A.R., 2013, 'They worship in our churches' - An opportunity for the church to intervene in order to diminish the corruption that is hindering service delivery in South Africa?', HTS Teologiese Studies/Theological Studies 69(2), Art. \#1933, 11 pages. http://dx.doi.org/10.4102/ hts.v69i2.1933

Read online:
This practical-theological study aims to develop a contextual theology in the areas of business and government that will aid a successful intervention by the church in diminishing the corrupt practices prevalent in South Africa. It seeks to prove that corruption is a major factor in causing the delays experienced in the implementation of service delivery, and that this is causing much anger and increasing disillusionment with the present system of democratic government. At the moment the church has a window of opportunity for this intervention to take place, since many of those responsible for supporting, organising and implementing service delivery, both in government and industry, worship regularly, as committed members, in local Christian congregations. A modified application of the Asset-Based Community Development $(A B C D)$ approach using focus groups is suggested as both a tool for intervention and for further research.

\section{Introduction}

\section{They worship in our churches}

One of the authors attended a meeting arranged by an ex-premier of the Free State with the clergy, representing various religions, three to four years ago. The purpose of this meeting was to discuss how the faith communities might help the government implement 'moral-regeneration'. The feeling expressed, almost unanimously, by those present, might be summarised as: 'We must first start with the moral regeneration of the ANC, at the national, provincial and municipal levels.' The ensuing discussion ended by a bishop saying: 'What are we doing wrong, because they (the government officials) worship in our churches?'

Our article aims to answer the bishop's question by formulating a suggested strategy indicating what church leaders can do to effect positive change. It does this within the framework of Osmer's (2008:4) four core tasks of Practical Theology, which are the descriptive-empirical, the interpretive, the normative and the pragmatic tasks.

This article is the outcome of a combination of two sets of experience. One author has contributed from his experience in education, at the highest-level of university management and, recently, as an ethical values consultant to business and government. The other has used the theological and pastoral experience he has gained as a minister in the multicultural Uniting Presbyterian Church in Southern Africa (UPCSA), from counselling congregational members in government and business.

\section{What is corruption and service delivery?}

The descriptive empirical task means that we must ask: Do we need to do anything about corruption? Before this can be answered corruption and service delivery need to be defined.

\section{Definition of corruption}

Definitions of corruption differ, but nearly all revolve around the concept of undue gain by a public official or functionary (for criticism of current definitions see Bracking 2007:4ff.). The simplest definition is given by Tanzi (1998:8): 'The abuse of public power for private benefit.' Sam Sole (quoted in Hollands 2007) expands on this, stating that corruption is, 'the wilful subversion (or attempted subversion) of a due decision-making process with regard to the allocation of any benefit.'

Copyright: (C) 2013. The Authors. Licensee: AOSIS OpenJournals. This work is licensed under the Creative Commons Attribution License. 
In South Africa, corruption is defined by the Prevention of Corruption Act (South African Government 2004) as an act which involves:

\begin{abstract}
Any person who - directly or indirectly - accepts or agrees or offers to accept any gratification from any other person, whether for the benefit of himself or herself or for the benefit of another person; or gives or agrees or offers to give to any other person any gratification for the benefit of that other person or for the benefit of another person, in order to act personally or by influencing another person so to act in any way that amounts to be illegal, dishonest, unauthorized, incomplete, or biased, or the abuse of a position of authority, a breach of trust; or the violation of a legal duty or a set of rules or designed to achieve an unjustified result or that amounts to any other unauthorized or improper inducement to do or not to do anything. (p. 16) (abbreviated by the authors)
\end{abstract}

It may involve such actions as: bribery which is the offering of a benefit that influences the decisions of a public servant in your favour; fraud, which is any action by a public servant that fools others into providing a benefit that would not normally accrue to that servant; favouritism which is the award of services or resources to those with whom the public servant has personal affiliations; embezzlement, which is the theft of resources by persons entrusted with authority and control of such resources; and nepotism, which is a state official ensuring that family members are appointed to positions or receive contracts from state resources. ${ }^{1}$ These definitions concerning corruption are deficient in that they do not explicitly cover corruption in the private sector. Private sector corruption is discussed later on in this article.

\section{Definition of service delivery}

One of the best definitions for service delivery, which applies equally to South Africa is:

public services ... which are funded with public money. These public services can be delivered by the state or on behalf of the state, for example by a voluntary and community organization (VCO) or private sector company. ( $\mathrm{NCVO}^{2} 2013$ )

This is a preeminent obligation of any government. In South Africa it involves providing and maintaining citizens with such services as roads, health care, housing, education and water. These services are fundamental to the well-being of a population and thus have an important impact on the nation's well-being, development and productivity. Because of the great amounts of money and many levels of participants involved, the service delivery sector is highly vulnerable to corruption. Since the poor are most in need of basic services they are the ones most affected by this (Zausmer \& Hawtin 2012:3).

\section{How serious is corruption in South Africa?}

Now we ask as part of the descriptive-empirical task: Do we need to worry about corruption in South Africa? There is no

1.For a more inclusive list see Bracking $(2007: 5,6)$.

2.This abbreviation stands for National Council for Voluntary Organizations. The NCVO is a UK-based organisation funded by the United Kingdom government. doubt that South Africa is not the only country to suffer from corruption. The enormous cost, world-wide, of corruption is demonstrated by the fact that the World Bank estimated that the cost to the global economy of bribery alone was $\$ 1$ trillion (Fitzsimons 2007:56).

In fact, overall, the Transparency International Perceptions Index of Corruption reveals that South Africa is still some way from being the most corrupt country in the world. It ranks at 4.9 (out of a mark of 10 for very little corruption). Although this is far from a healthy situation, it puts South Africa at a better than average 54th, out of the 180 countries on the index (Lambsdorff 2008:395). The situation is worse with the 'Bribe Payers Index', but even then South Africa is not the worst country, being listed at 14th out of 22 countries (Riaño 2008:404). Yet despite this, as pointed out below, it needs to be recognised that in the South African context corruption has far more serious consequences for service delivery implementation than in wealthier countries.

Corruption can no longer be dismissed as 'unproven' or 'alleged'. De Wet and Kruger (2013:5) give good reasons to accept that it is a fact. The allegations of corruption and the consequences for service delivery are made by many who are in a position to 'be in the know'. For instance, Thabo Mbeki (quoted in Hollands 2007: frontispiece page), in addressing the National Council of Provinces, speaks of the 'unseemly scramble [sic] by municipal authorities to be elected', because those who are elected can 'determine the outcomes of municipal tendering processes.' More recently, Bateman (2012:777), a medical doctor, estimates that in South Africa's public healthcare sector losses due to wastage and fraud or corruption must be billions of rands.

\section{Corruption contributes to the crisis of frustrated service delivery expectations}

Service delivery is of vital importance in South Africa, since it has been promised, is expected and is seen as necessary by the poorest to the wealthiest, for the development of the country in many spheres. If corruption prevents effective, speedy service delivery, then the country is in trouble.

The siphoning off or misappropriation of money allocated for service delivery reduces the amount available in the national fiscus. In a developing country like South Africa less is available anyway than in wealthier countries. This reduction is compounded by an unwillingness of international and local investors to entrust their investments to a country with a reputation for corruption. They do not know what will happen to it, how wisely it will be used and what the rate of returns will be on that investment. An uncertain climate always deters investors.

Corruption also reduces the financial resources available for service delivery, since what is available is not spent in the most effective way. Arcane political decisions, based on favours owed and future election prospects, do not direct it to the most worthy or needy people or areas. At a lower 
level the most efficient and skilled firm(s) may not be given public service tenders. This will mean that because of inferior workmanship the end product is of poorer quality, will not last as long, and sometimes has to be paid for again to be redone, which has actually happened, for instance, with many Reconstruction and Development Program (RDP) houses (Chan 2011:120).

Ultimately, all are economically impoverished by corruption. This may be concluded from the fact that Lambsdorff (2008:396) estimates that an improvement in the Corruption Perception Index by one point would be associated with an increase in per capita income of almost $4 \%$ in most countries. This demonstrates clearly the devastating impact of corruption on the livelihoods of ordinary people and that rooting out corruption would solve many of South Africa's economic and unemployment problems.

In these circumstances, not only, but especially the poor become incredibly frustrated and angry at not getting the service delivery that the politicians have promised. This anger is directed, in the first place, at government, because the public believe, as has already been stated, that many government officials are corrupt and have used some of the money available for service delivery to enrich themselves. According to the results of the South African Social Attitudes Survey (SASAS), conducted by the Human Science Research Council (HSRC) in June 2012, (Gordon et al. 2012:12-15), the most commonly cited departments or state entities where corruption is perceived to be rife and endemic are Home Affairs, South African Police Services and Public Services.

\section{Corruption is perceived to be on the increase}

What is sounding alarm bells is that $74 \%$ of South Africans now believe that the incidence of corruption has increased in the past three years. This is aggravated by the fact that the presumed beneficiaries of corruption are now observed flaunting their wealth with life-styles which are the envy of the less fortunate. Moreover, as Du Plessis and Breed (2013:1) comment, '[it] is precisely the poor and the vulnerable who suffer most under corruption', and this demographic majority constitutes the most potentially disaffected section of the population.

\section{Corruption in the private sector is also affecting service delivery}

However, it is not just corruption in the public sector that hampers service delivery and creates discontent and anger. In fact, some allege that corruption is more widespread in the private than the public sector, thus depleting the public fiscus even more. For instance, it is alleged that R1.5 billion has been lost to the South African government fiscus by tax avoidance schemes (Ex Judge William Heath, quoted in news24, 29 March 2010). There is much evidence that bribery is becoming the norm in the private or public interface, either demanded or supplied (Business against Crime 2007:3), as is collusion between companies (ibid:12). Examples of the latter include the oligarchic price fixing practice of bread and other wheat and maize products amongst Tiger Brands, Premier Foods, and Pioneer Food, uncovered within the last few years (West Cape News 29 January 2013). Global firms have also allegedly been involved in corrupt practices in South African deals. In 2003 the Guardian Newspaper published articles into alleged bribery by BAe System's (Britain's largest arms manufacturer) in the Czech Republic, India, Qatar and South Africa. It was reported that BAe Systems was providing prostitutes, sports cars, yachts, first-class plane tickets and other inducements (Evans 2009: 154-155).

\section{The long term serious consequences of lack of service delivery}

As Burger (2009) comments: 'The long term repercussions of this dissatisfaction with service delivery may be very serious. It has the potential to spread and develop into a fully-fledged revolt.' If the moral climate is not changed and the anger continues to grow some are even predicting that South Africa is heading towards becoming an ungovernable failed state, as in some other countries with high indices of corruption.

\section{What then can the righteous do?}

If it is conceded that corruption is seriously hindering service delivery, which in turn will have serious consequences for the South African fledgling democracy, then it should be a matter of grave concern to all. No more so than in the church, which has a God-given prophetic mandate to care for the well-being of society, as the missional servant church, which in this case means seeking to facilitate the implementation of service delivery. We again ask: Can we do anything?

Praxis in South Africa has revealed that the current rate of corruption is so serious that it may threaten the future stability of the country. Two psalms, 11 and 82, appear to have been written in similar circumstances to which South Africa finds itself now. The two psalms, particularly Psalm 82, appear to be of very ancient origin (Brueggemann 1997:143; Loretz 2002:268-273). Hence, these psalms demonstrate that from the earliest times corruption was commonplace throughout the milieu of the ancient Near East. These two psalms also indicate ways in which the people of God have reacted to corruption. Both psalms contain a strong element of hope but also emphasise the serious consequences of not doing anything. Therefore, they may be able give us guidance as to some of the solutions needed in today's world.

\section{The psalms express dismay at corruption because society is destabilised}

The author of Psalm 82 describes the results of having people in authority whose actions are not constrained by concerns for holiness, justice and the vulnerable (v. 3) as being that, 'all the foundations of the earth are shaken' (v. 5). And the author of Psalm 11, in the third verse, expresses a seemingly powerless dismay and fear at this: 'When the foundations are being destroyed, what can the righteous do?' (Stek 2008:801) 
These two psalms are attributed in the Masoretic text to different authors, and may well have been written at widely different times. Yet both are linked by a concern for the 'practice of justice for the sake of community' (Brueggemann 1997:428). This translates into concern about the social instability that accompanies a lack of this justice due to a complete breakdown of law and order (Bratcher \& Reyburn 1991:111).

The term 'foundations' is used to describe the underlying trust and morality which upholds the social stability that is the foundation of society and the world order (Stek 2008:801, 880). Both authors describe the results of this destruction of the social order in terms that express the 'foundations' as being destroyed or shaken. The situation is serious because in the absence of trust and morality the whole world order (the foundations) crumbles (Ps 82:5). The psalms indicate that the result of unbridled, unchecked corruption may even lead to a failed state, with world-wide consequences (Goldingay 2008:264). When faithless people ignore or oppress the poor with impunity, and no one does anything to rescue them, the very structure of human existence is imperilled. Yet the question: What can the righteous do?, is answered positively in both cases.

\section{Psalm 82 is an example of confronting corruption with 'people power'}

The answer given in Psalm 82 depends upon who the 'gods' are. The 'gods' spoken about here are most commonly interpreted as Canaanite gods or human leaders and kings (Goldingay 2008:559). Tate (1990:341) comments that 'despite its exegetical weakness the old tradition of relating Psalm 82 to human actions has a strong element of truth in it.' This truth is that the gods of the nations are responsible for the types of rulers and officials who rule them, because of the nexus the Bible reveals between the heavenly and earthly realities. Thus, judgement upon these gods is also judgement upon their human agents.

Psalm 82 may thus be legitimately interpreted as God castigating kings and rulers (aptly called gods) for their partiality (unfair bias) to the wicked. These so-called, 'little' gods are reprimanded for being devoid of a true understanding of moral issues (Collins 2008: loc 145602). This is seen as resulting in the oppression of the most vulnerable in society, which God hates. The psalmist (vv. 1-4) testifies that God expects power to be exercised in solidarity with the weak and needy (Brueggemann 1997:143). Those with power, such as political and governmental leaders, are in a unique position to enforce justice, punish corruption and set the moral tone for those they rule. In today's world this would translate into the attitudes, actions and incorruptibility which are needed to effectively implement service delivery.

What recourse, then, do those who are concerned about this situation have? The answer of Psalm 82, as exemplified in verse 8 ('Rise up, O God ...'), is to pray. This prayer is more than just an eschatological call for some future justice; it is foremost a prayer for the implementation of judgement and justice now. Moreover, not everything is to be passively left to a sort of 'deus ex machina' intervention by Yahweh. It is also a prayer that justice would be done by God through his people (Boice 1996:679). As such, it is suggested that the psalmist himself sets the example by praying or singing this 'prayer psalm ... aloud in the Temple during Temple worship, probably in the hearing of the unjust "gods", whom he portrays as being indicted by Yahweh' (Goldingay 2008:559). This may be seen as the first step in the utilisation of 'people power' (or rather 'people of God' power) to influence, firstly, corrupt leaders and then mobilise the worshipping community into action.

\section{Psalm 11 is an example of discovering the resources that God provides to withstand evil}

A slightly different answer is given in Psalm 11. Here the righteous are those who are concerned because, 'they honour God and order their lives in all things according to his will ... remembering that power and authority (of whatever sort, domestic, social, political, economic, religious or intellectual) are to be used to bless, not to exploit' (Stek 2008:790). In today's world when roads are not built, RDP houses fall down, sanitation is not laid on, schools and teachers are not provided, and hospitals deteriorate, so that the ill and infirm are not cared for, then God-given power and resources are not being used to bless.

The answer the psalmist gives to this lack of blessing is not to run away from thinking about the problem or to emigrate to a place where it does not occur (to fly away like a bird as v. 1 puts it). This would be a tempting option for the righteous, because they are being intimidated by the 'wicked' (those who are not interested in obeying God's laws and think they can do what they like) and are rightly (see v. 5) fearful and feel powerless to do anything (Goldingay 2008:188, 191). Instead, the Psalmist encourages himself and others to begin to stand firm and fight moral corruption by looking up to Yahweh in his holy temple (v. 4). This visual spiritual imagining of the Temple will link them in to the reality of the invisible Yahweh. The aim is that Yahweh's being and character will become so all-consuming that disbelief, fear and powerlessness are overcome by faith, courage and power for and in action. Yahweh knows everything that is going on in the shadows and hates it and is ready to act so that the righteous can take refuge in him (v. 1) (Brueggemann 1997:668)

There are in fact many answers offered in the Bible:

When the foundations collapse you can flit (like Elijah), seek to rebuild them (like the Deuteronomist), preach (like Amos), tell stories to build faith (like Genesis), promise a better future (like Isaiah), or feel overwhelmed (like the author of Ecclesiastes). Or you can just stand tall and look for God to act, like the author of Psalm 11, knowing that Yahweh's acts do not lie in some distant future, but now. (Goldingay 2008:194) 


\section{The starting point - the recommendation of Psalm 11 to think about God}

We will be reflecting on most of these actions, but begin by discussing the 'looking up to God in his holy temple.' The motivation for all moral intervention by God's people has to be preceded by the faith and conviction that only come by reflecting on God. Much to the distaste of our actionorientated, pragmatic society, we must study what God has to say in his word, and theologise, so that the principles we learn can be applied to everyday life. This is by no means all we should do, but it must be the beginning. We can arguably say that this seeking to theologise might be described as the normative task in practical-theological terms.

This systematic reflection does not attempt to be a postmodern detailed exegesis but rather a 'modern' interpretation that is unashamedly from a conservative, evangelical Reformed perspective. This approach is taken in the light of the intended outcome, namely, to communicate this message to church leaders to empower them to preach with conviction. It is the experience of the authors that many congregational leaders in the communities most affected by corruption have little understanding of what the postmodern method is, English is only a second or third language, and they accept the authoritative witness of the scriptures, unbothered by the critical method, for better or worse. However, it must be borne in mind that the suggested recommendations for implementation of this theology at the end of the article are of - what we believe to be - a thoroughly postmodern nature.

\section{What does God's Word teach us about government and business practice?}

\section{God's intrinsic detestation of all forms of corruption}

The scriptures reveal a God of justice (e.g. Job 37:23, Ps 9:16, Ps 36:6). He is impartial (Dt 10:17, Ac 10:34, 1 Tim 5: 21, Ja 3:17, 1 Pt 1:17), and cannot be bribed (Dt 10:17, Ac 10:34, 1 Tim 5: 21, Ja 3:17, 1 Pt 1:17). He detests corruption and bribery, along with all unethical practices, as these offend his character. He particularly abominates corruption because he is a God of love and compassion (e.g. Ex 34:6), who cares for the poor, vulnerable and defenceless in human society. This means that not only does he have an absolute detestation of corruption, because it ethically wrong, but also because it results in the exploitation, oppression and impoverishment of society and obstructs the service delivery everyone needs, and the poor in particular.

\section{Corruption's perversion of God's service delivery program}

These wrongs are even more detestable because they corrupt the revelation to humans of the image of God, which he created the universe to display. He created a good universe for his good purposes in order to express his overflowing goodness as indicated by Romans 1:20 (Moo 1996:1-19). Then he created men and women so that they might mediate 'within creation the immanence of the transcendent Creator' (Grenz 2005:88). He wanted men and women to be fruitful and multiply and rule the earth (Corbett \& Fikkert 2009:58). This might be called God's 'service delivery program' for humankind, provided the analogy is not taken too far.

The entry of sin has made the above impossible to attain, but it is still his plan 'A' for human society. God still desires humankind to abound, enjoy his goodness, and develop socially, intellectually, technologically, and culturally (Alexander 2008: loc 24820ff.). The developmental state striving to effect service delivery by improving the economy and infrastructure, educate its citizens, and care for their health and uplift their standard of living, is thus close to his heart. To this end he established two institutions which are built into the character of humankind, which are government and business. Later he added the church so that His good purposes would be achieved through redemption in Christ.

Yahweh established governments and other legitimate human institutions (Rm 13:1-6; 1 Pt 2:13-17), because good governance that seeks the welfare of the governed and enforces the rule of law is necessary for the development he desires. Thus, the rulers and kings of Israel and Judah were expected to be devoted to the welfare of their subjects, especially the poorest and weakest members of society (Ps 72:12-14). By upholding the divine principles of law and justice, rulers promoted peace and prosperity for all their subjects.

\section{The issue of governance is a matter of life and death to God}

Leaders and rulers (1 Sm 8:3) are not there for self-enrichment, which distorts decisions, but to serve. Self-enrichment distorts the fundamental purpose of leaders in all societies and is denounced many times over in the Bible: 'The issue of the governance of human affairs is a matter of life and death to God Almighty' (Tate 1990:337). Hence, some of the strongest societal condemnations in Scripture are reserved for kings, governments and leaders who do not do this because they are partial, unfair, expect bribes, in order to enrich themselves (Ps 82, Ezk 22:23-29, 34:1-10, Mi 3 etc.)

The implications of this are that kings, rulers and leaders, that is those with power and authority, establish the moral tone of Yahweh's people and nation. Whilst there was a delicate relationship between kings, prophets and priests, the king had the ultimate influence, and any change had to come through him, even if it was initiated first of all by the priests and/or prophets. As Howard (1990:113) comments, 'the godly king led the nation in worship and keeping covenant.' The book of Deuteronomy makes it clear that 'keeping covenant' had many moral obligations, including punishing corruption. 


\section{The role of business and trade for God's service delivery program}

The second institution was that of business, trade and commerce. Genesis 1:28, 'be fruitful and multiply and fill the earth and subdue it and have dominion ...', carries this implication. Indeed the word 'subdue' has the idea that humankind is to make the earth's resources beneficial for themselves (Alexander 2008: loc 24818). Trade, business and commerce played and play an essential role in fulfilling the command found in Genesis 1:28.

It is nowhere explicitly stated in the Bible, but when we look at men and women we see that the desire to trade appears to be an essential part of the human character. This propensity to trade appears to have been implanted in them from the beginning, and thus must be related to humankind being made in the image of God. As Adam Smith ([1776] 2013:7) comments: humankind has an intrinsic 'propensity to truck, barter and exchange one thing for another.' This propensity includes discovery, finding out and exploring what is new, networking, sharing, swapping, production, possession and maybe delight in bargaining.

Thus trade and exchange have played a crucial developmental role in history, 'being perhaps the most important external stimuli to change ... and development in art, science and technology' (Curtin 1984:1). Archaeologists have found evidence of long-distance trade dating back to prehistoric times, perhaps as much as 60000 years ago (Bernstein 2008:8). Even though the good results of this desire to trade have been corrupted by sin, resulting in greed, exploitation, cheating and corruption, it still has an overall beneficial result. Evidence for this is that Tyre is not condemned for its trade in Ezekiel 26-28; indeed its prosperity seems to be applauded and to have brought benefit to many (see esp. Ezk 28:11-15). Instead it is condemned for the pride and self-reliance that accompanied the growth of their successful trading empire.

Indeed, it seems that business is so essential for the welfare of all, that the Bible testifies that God seeks to regulate it, as well as government. It is clear that society cannot develop and realise its God-given potential without the trust that allows trade, commerce and business to flourish. He therefore detests dishonest businessmen who bribe and cheat, and thus destroy social trust, in order to make unfair profit ( $\mathrm{Lv}$ 19:35, 36, Dt 25:13-16, Pr 11:1, 16:11, 20:10, 23, Hs 12:7, Am 8:5-7, Mi 6:10-11). Only honest and faithful stewardship in business, as well as in government, produces the abundance and development God intends and fairly distributes that abundance. Thus, God's desire is that his people, especially influential leaders, take a stand against corruption.

\section{Examples of those who resisted corruption}

Such were Daniel and Nehemiah, who contributed to effective service delivery in the Persian Empire and Jerusalem respectively, through their stand against corruption. Daniel is held up as an example of a righteous ruler, being a top government administrator, in whom even his enemies could find no evidence of negligence or corruption (Dn 6:4, 5).

It is interesting to note that Persia was the first empire to introduce the exchange of goods for coinage so as to become a monetary economy. The resulting increased trade across the empire necessitated that transportation and travel became more efficient and effective. Thousands of miles of roads were built and even a postal service was introduced to link up this enormous domain. Along with the construction and improvement of existing roads, a public works system was introduced and a standardised weights and measures system was also implemented (Bright 1972:375; Hayden 2012).

It is quite possible that in his role Daniel would have had to handle the allocation of tenders for the Persian emperor that resulted in, what may be described as, the first historically recorded service delivery program. His incorruptibility would have earned him enemies because it restricted opportunities for contractors and lower officials to enrich themselves by overcharging and/or collusion on tenders and/or embezzlement of the finances.

Nehemiah (Neh 5:14-15) is recorded as proclaiming that his administration (in the 'Jerusalem municipality') was incorruptible and that he had not enriched himself at the expense of the Jerusalem tax payers, as previous governors had done. He was there for the benefit of those he governed by improving the security needed for trade, commerce and social interaction to flourish, by rebuilding the wall, which may be regarded as a form of service delivery.

In conclusion, the Bible indicates that corruption flourishes when it is not punished by the ruling authority, is practised with the connivance of the religious community (Ezk 22:26), and no one is prepared to stand openly against it as Daniel and Nehemiah did. Moreover it would seem that it proliferates whenever there is a lack of transparency and openness in government and business. This emphasises once more the relevance for today's praxis of Psalms 11 and 82, which speak of the morally corrupt as shooting from, 'the shadows at the upright in heart' (Ps 11:2) and walking about 'in darkness' (Ps 82:5). As Tate (1990:337) comments, 'the darkness may be what they use to cloak their deeds.'

\section{The implications of this theology for South African society}

The theological study underlines and confirms the 'commonsense' results of corruption often put forward by economists and others mentioned under the heading 'How Serious is Corruption?' However, it not only confirms the deleterious effects of corruption and its effects on service delivery, but also suggests that it has additional adverse spiritual, moral and social consequences.

The most important result, in so far as Christians are concerned, is that all who practise corruption will be judged 
by the great King of Psalm 82, either here or hereafter. There is no such thing as 'cheap grace' (Bonhoeffer 1964:35). God is impartial in all his dealings and desires this characteristic of impartiality to be demonstrated in all his covenant people. As Folarin (2010) comments from his study of Luke 12:13-21:

The fight against [corruption] ... requires the theological motivation that there is a God to whom humans are accountable ... This differentiates a purely humanistic from a religious approach to fight covetousness. A humanistic approach to fight covetousness may be driven by the thought of accountability to other humans; the religious approach is driven primarily by the thought of accountability to God. The guilty person can escape humans, but definitely not God's judgment. (p. 321)

It also suggests that there are theological grounds for believing that widespread, unchecked corruption will lead to a widespread moral decline within society. All are morally impoverished by corruption. Those who practise corruption are impoverished because their character and ability to make ethical decisions degenerates, which contaminates other areas of their lives. Society is morally impoverished because those who practise corruption tempt others to do so by their example. They also exert overt or implicit pressure upon those over whom they have authority to co-operate with them, sometimes warning of punitive action if they do not. As a result the poor and defenceless in society are inevitably the main victims, because of either their gullibility or ignorance of economics, or because they have no powerful protectors.

More seriously, the theology indicates that corrupt governmental and business practices do actually destroy the foundations on which a nation is built. When those in power depart from Yahweh's will for justice, public power can no longer be sustained (Brueggemann 1997:615). Thus there is no one to enforce the trust needed: trust between the government and the governed; trust between merchants so that they can trade and practise commerce and business without having to take expensive precautions against fraud; and trust by all that the rule of law will be upheld. Stiglitz (2003:274), 2001 Nobel Prize Winner in Economics writes: 'What makes business systems work, by and large is trust ... In recent years, in failed societies, we see disastrous consequences for the economy of the breakdown of trust.' Corruption diminishes trust in government and leads to people trying to avoid taxes and other government dues. It also adds to a general legitimisation of criminality. If they can 'get away with it' why not me!

\section{The causes of corruption in South African society}

The causes of corruption are extremely complex in South African society and much more research needs to be done, if they are ever to be uncovered. Yet they need to be considered to be countered. We do this by each sharing our own perceptions. In the case of South Africa, where so much seems to be focused through the perceptions of identity, it seems wise when looking at the causes of corruption to take into account the differing cultural backgrounds of the authors by listening to their individual perceptions separately.
Khotseng shared that many are now asking: Why is corruption so rife in the new democratic South Africa? What are the roots of corruption? Many are aware of the paradox that, although there is great awareness of the need for responsibility and transparency amongst officials in government services, yet public officials seem to become more corrupt, so much so that it is becoming a way of life at all levels and the secrecy behind which corruption hides is increasing all the time.

Khotseng sees two main causes for this. Firstly, he suggests that some of those who were cheated, oppressed and prevented from being socially upwardly mobile during the apartheid era have developed a culture of entitlement. They believe that it is not wrong for them to cheat now, in order to acquire what should have been rightfully theirs, all along. This may have been further encouraged by the strongly assertive ideological affirmative action program implemented by the government. This argument makes sense, but it does not help to advance or develop the country morally, economically or socially.

The second cause may be the traditional cultural practices of gift-giving, the reciprocal granting of favours, clientelism, and almost expected compulsory showing of preference towards members of one's own family, clan or tribal groups by its members. In fact some research, coming out of India, seems to indicate that once what we now regard as corrupt practices are established in an area or culture, benefitting the socially dominant, they are very persistent and difficult to eradicate (Pandey 2010:190).

These factors have led to the creation of a society with a culture of impunity where corruption is equated with the path to wealth and status.

Tucker regards corruption as being the historic legacy of a South African settler or immigrant society. It became endemic in a South Africa where many were historically far removed from the authority of the State, which allowed extensive, mainly unchecked, corruption under the rule of the Vereenigde Oostindische Compagnie (VOC) (Welsh 2000:90). Both under the Dutch and British governments many immigrants came to South Africa to improve their lot, whatever it took to do so and no matter whom they exploited. This was exacerbated by the greed and corruption, on a vast scale, which accompanied the diamond and gold field rushes in the nineteenth century, especially in the area of private enterprise. Such propensity to corruption was not improved by 'the notorious corruption of the Nationalist government' (Welsh 2000:522).

There is thus a general measure of agreement between both authors concerning these causes. If our perceptions prove correct, then Pandey's (2010) research in India, quoted above, would also apply and explain the persistence of corruption at all levels of society in South Africa amongst all culture groups. In addition, both agree that due to the fact that human nature is corrupt, unless there is strong supervision with good administrative accounting systems with the will to enforce sanctions, corruption will run riot. 
This 'will' appears to be lacking in the government at the moment, as is confirmed by Chan (2011:59). His research indicates that 'the beginning of corruption, although minor by comparison with other African countries, allowed many to become "equal" swiftly with rich white elites.' Black Economic Empowerment has led to the formation of a privileged Black business class that has led to new chains of corruption (Chan 2011:114). According to Chan (2011:201), the patronage system of acquiring and keeping political power introduced with a 'vengeance' [sic] by the current President is now entrenched

Both authors believe that South Africans must choose what kind of society they would want to live in. The question must be asked: Do we want to have a corrupt society, as in the Philippines? This is a society traditionally dominated by a culture of gift giving, reciprocity, and clientelism with extreme corruption, where political office is seen mainly as an opportunity to acquire wealth, a privileged life-style and upward social mobility (Estifania 2007:129). Or do we want an efficient, honest and open society that rewards merit, where political office and government administration are seen primarily as a means of serving and benefitting society without undue enrichment?

\section{The actions our theologising suggests may combat corruption in South Africa}

'Forming and enacting strategies of action that influence events in ways that are desirable' (Osmer 2008:176), may be seen as Practical Theology's pragmatic task.

\section{The apparent ineffectiveness of current strategies}

A number of approaches have been suggested from the secular world. No doubt these have helped increase awareness of what corruption is, in government and business, and that it is harmful. Yet Bracking (2007:3) is not very optimistic about the results of previous government interventions, campaigns and business ethics' seminars. She writes that the campaign against corruption 'may be one of the final episodes in a redundant development intervention paradigm illustrating the weakness of the expert-led, sanitised, technocratic development process.' In similar vein, Heitink (1999:210ff.) comments that the use of pedagogical strategies to effect changes presuppose that people are prepared to change their behaviour. This is an unwarranted assumption even when they perceive the desirability of change. This would be our criticism of Zausmer and Hawtin's (2012:11ff.) proposal that increased transparency on the part of governments will help alleviate the problem, if accompanied by heightened community awareness. Whilst this will no doubt help, to some extent, it is insufficient.

\section{Three interventional strategies based on recent ideas}

Something new is needed. Three interventional strategies are suggested in order to mobilise church leaders and their congregations, namely, (1) focus groups; (2) ethical proclamation mainly by church leaders; and (3) Asset Based Community Development (ABCD). The strategy begins with listening, using focus groups, then proceeds to input through ethical preaching, and lastly, implements through community driven action, using the $\mathrm{ABCD}$ approach.

As yet we have purposely avoided setting down a list of rules on how to combat corruption in daily life. We believe that we are only at the initial stages of research and that, anyway, the ideas and do's and don'ts must come from an interactive dialogue between theology and the community, the results of which are yet to be established. Much more research needs to be done, for which funding needs to be found!

\section{Employing focus groups}

As in Psalm 82 the people of God affected by corruption first need to be heard. It is therefore suggested that the initial step is research employing focus groups. We need to listen to the leaders and the people about how corruption affects their lives, how they perceive this, and what their beliefs are concerning its practice. Osmer (2008:54) defines a focus group as a group of fewer than ten people in which verbal data are gathered under the guidance of a discussion leader. This approach is ideal for the purpose of seeking community driven solutions to the problems that civic and business corruption is causing for service delivery. It may also help to bring to light the deeds of the darkness under the cover of which the corrupt love to act, as evidenced in Psalms 11 and 82 .

Hence, the first interventional strategy aims to focus upon gathering qualitative data about a particular target group's experience of a 'particular concrete situation' (Stewart, Shamdasani \& Rook 2007:9). It is suggested that the initial target group be 'clergy', who subsequently extend it to focus groups within their congregations. This research will then be used to interrogate the theology developed in this article in order to move towards a new theory facilitating realistic, contextual, interventional praxis in order to mobilise the people of God.

\section{Ethical proclamation}

We also believe that a large part of the answer lies, as Psalm 82 indicates, with the mobilisation of the people of God (the church) through their leaders. Yet many are silent. Perhaps this is due to the fact that they do not see that 'churches have the responsibility to engage in the struggle against corruption by raising ethical awareness ...' (Vorster 2012:133). Perhaps this is due the tremendous pressure most church leaders are under to only preach what their congregations want to hear and, often, to conform to the mores of the social structures and culture in which they live.

Perhaps this silence is due to fear. Indeed, Ramphele (2013a, 2013b) in two recent speeches has stated that fear is preventing many South Africans from speaking out against corruption. In addition, church leaders, perhaps more than 
others, are often tempted to despair about being able to change anything (as the psalmist was in Ps 11). In this case, neither leaders nor people will be mobilised, until they overcome the fear of speaking out (see Ps 11:1-2) as well as their sense of powerlessness (Ps 11:3), and until they are convinced that God hates and judges corruption and of the seriousness of the situation for the foundations of South African society (Ps 11:3,5). Probably only then will they be motivated to combat corruption, because they perceive that doing so is more important than prevailing tribal, political interests, patronage and other advantages. Only then will they be prepared to face the very real threat of violence being used to prevent them speaking out or as punishment when they have (Ps 11:1, 2, 5).

It is suggested that only input through the Word and Spirit will produce sufficient conviction to overcome these serious and very real obstacles. We therefore suggest that the next stage is to motivate church leaders to action by asking them to 'look up towards the holy temple' so as to expose them to God's omnipotence, character, revelation, knowledge of and hatred for corruption and its theological and empirical practical consequences for the church and the nation. The aim would be to facilitate theological thinking about the corruption, allowing the leaders to interrogate their new understanding by asking questions arising from the current praxis, so that the answers can be applied in a relevant manner. As a result we are enabled to make definitive statements about the topic in an accurate, coherent and relevant way. Then the Holy Spirit is able to use our conviction, with its resultant transparency and sincerity, to convince others.

The resultant prayerful preaching, coming from a deep conviction, could well be very effective in mobilising congregations in the South African majority oral culture, as De Wet and Kruger's (2013:3) research into the ethics of the kingdom of God suggests. This research led them to advocate the effectiveness of the role of ... prophetic preaching in addressing the apparent lack of righteousness as it manifests in a context of corruption in the South African society.' As a result they and their congregations will be given the opportunity to become convinced, not only of the seriousness of corruption, but also that there is a solution, and that they may become part of the solution, if they depend upon God.

\section{Asset Based Community Development}

Finally, it is recommended that for this to be really effective the church needs to be given hope, that the God who sees the problem has (also) already provided the resources within the community to deal with the problem. It is suggested that a proven approach to achieve this is that of Asset Based Community Development. The 'assets' are any resources that a community has within itself to develop, change, and combat problems.

The concept operates from the principle that this is God's world and the church is not bringing Christ to poor communities. He has been active in these communities from the beginning of the world. Thus, a significant part of working in the poor communities, that are most affected by corruption, includes discovering what God has been doing there for a long time and then facilitating its use. Researchers and congregations which are empowered by their wealth and education are not superior, but have much to learn from them (Corbett \& Fikkert 2009:129ff.)! It is from this perspective that the $\mathrm{ABCD}$ approach asks: 'What can this community do by itself to achieve its own goals and dreams?' (Van Groningen 2007:4)

The triune God has especially been at work in the community of the church, in which he lives (Eph 2:19-22). Brueggemann (1997:668, 670) describes Israel's preoccupation with the temple in the Old Testament. It was a focus for their faith and actualised for them the reality of God's presence amongst them, motivating the psalmist to lift his eyes to the temple in Psalm 11 to get in touch with the presence of God. In doing this the psalmist is saying, 'God is really here. He is my resource in whom I may take refuge and be empowered to act.' As the church we have greater resources than the psalmists, since we ourselves are the temple of the Holy Spirit, in whom God dwells (1 Cor 3:16). God is not here in one location but here in every Christian and congregation. We do not need to look upward but inward.

One of these resources is the gifts he gives to his Body, the church. Du Plessis and Breed (2013:6) summarise 1 Corinthians 12 as follows: God has resourced the Body of Christ with Spirit-filled members to whom he has given gifts. These gifts enable God to work powerfully and effectively through their service work, so that through the gifted-people transformation happens according to God's plan.

Yet many who suffer the effects of corruption consider themselves powerless victims. They suffer the natural feelings of inferiority and shame (Corbett \& Fikkert 2009:64, 65). Jayakumar's (1999) research reveals that when they are presented with solutions and decisions made by the wealthy and educated, these feelings of inferiority are reinforced and the solutions are never internalised and made their own.

So the community will need to be empowered. Within the communities Christian leaders serving there are indeed the needed resources, but both leaders and communities need to discover them and be mobilised. ABCD is a method for this empowerment and mobilisation, through helping communities discover their gifts, skills, resources and associations by means of which they can deal with the problem.

Many church and faith based communities report that they have found much transformational success in using this approach (see Rans \& Altman 2002). ABCD is often initiated by using the learning research process of interviews and story-telling of appreciative inquiry. This process seeks to discover a community consensus, which then becomes the reference point for further community action (Mathie \& Cunningham 2002:7). 


\section{The advantage of combining the three approaches}

The advantage of this threefold approach, focus groups, ethical proclamation, and $A B C D$, is that it increases the opportunity for 'buy-in' or 'ownership' of the problem within a thought-through theological framework which will increase the potential for community mobilisation. Ownership is enabled to arise because communities have been listened to. Empowerment occurs because of theological conviction and dependence upon the Word and the Spirit. Relevant contextual solutions are proposed and committed to because the community, who daily lives the problem, discovers its God-given resources.

This process may even be a lever for changing the attitudes of politicians and businessmen towards corruption. The attitude of the political leadership will seriously change when they see that indulging in and permitting the corruption that hinders service delivery will get them voted out of office. The attitude of the business world will only change when they discover that greater profits are to be made in a society where corruption is not permitted, and as a consequence the work-force are better educated, healthier, and enjoy a higher standard of living through efficient service delivery.

\section{Conclusion}

We must be aware that there has always been a:

widespread human tendency of individuals to prefer their own interests to those of others. Humans tend to be biased toward members of their own groups, to steer away from outsiders and to rationalise self-serving behaviour through morality. (Vorster 2012:142)

Only an experience of the work of Jesus completed on the cross can free men and women to make the right choices. And only God, the Holy Spirit, received at the new birth can convict us about what is sinful and can empower us to enact these choices. Only then will men and women receive the grace they need to want to combat corruption, in order that the process of service delivery may be effective and enrich all in the nation.

Let us not fail to climb through this window of opportunity. In South Africa the church is at the moment in a unique position, compared to many other developing countries, to make an effective intervention in order to combat corruption because of the overwhelming numbers who profess to be Christians and worship in local congregations. But it is suggested that it begin with a theological reflection on the revelation contained in the Judeo-Christian scriptures. This reflection brings the conviction that Yahweh expects his people, in particular, to be incorruptible in both government and business. Thereafter also to the conviction that he expects them to take action against corruption as individuals with the support of the congregations and the communities these congregations serve.

\section{Acknowledgements Competing interests}

The authors declare that they have no financial or personal relationship(s) which may have inappropriately influenced them in writing this article.

\section{Authors' contributions}

This article is the outcome of a combination of two sets of experience. B.K. (University of the Free State) has contributed from his experience in education, at the highest-level of university management and, recently, as an ethical values consultant to business and government. A.R.T. (University of the Free State) has used the theological and pastoral experience he has gained as a minister in the multicultural Uniting Presbyterian Church in Southern Africa (UPCSA), from counselling congregational members in government and business. A.R.T. was responsible for the final drafting of the article and making the proof reading corrections, after both authors had discussed the returned peer review.

\section{References}

Alexander, T., 2008, 'Genesis', in K. Barker (ed.), Zondervan Study Bible, loc 1773821400, (Study notes loc 24657-28345), Crossway, Wheaton.

Bateman, C., 2012, 'Private healthcare, "Iost line in the sand"', South African Medical Journal 102(10), 776-777. http://dx.doi.org/10.7196/samj.6253, PMid:23162852

Bernstein, W., 2008, A splendid exchange: How trade shaped the world, Atlantic Monthly Press, New York.

Boice, J., 1996, Psalms, vol. 2, Baker, Grand Rapids.

Bonhoeffer, D., 1964, The cost of discipleship, transl. R. Fuller, SCM Press, London. PMid:14347758

Bracking, S., 2007, 'Political development and corruption', in S. Bracking (ed.) Corruption and development, pp. 3-27, Palgrave Macmillan, New York. http:// dx.doi.org/10.1057/9780230590625

Bratcher, R. \& Reyburn, W., 1991, A handbook on Psalms, United Bible Societies, New York. (UPS Handbook Series).

Bright, J., 1972, A history of Israel, 2nd edn., SCM Press, London.

Brueggemann, W., 1997, Theology of the Old Testament, Fortress Press, Minneapolis.

Burger, J., 2009, 'The reasons behind service delivery protests in South Africa', in Institute for Security Studies, viewed n.d., from http://www.issafrica.org/isstoday/the-reasons-behind-service-delivery-protests-in-south-africa

Business against Crime and GTZ, 2007, Research report on corruption in the South African private sector, 14 February 2007, viewed n.d, from http://www.nacf.org. za/business/BAC_Corruption\%20Report_KD_13Feb07_v1.pdf

Chan, S., 2011, Old treacheries, new deceits: Insights into South African politics, Jonathan Ball Publishers, Jeppestown, South Africa.

Collins, J., 2008, 'Psalms', in T. Lane \& W. Grudem (eds.), ESV Study Bible, Kindle Version, loc 120719-121143, (Study notes loc 120696-149032), Crossway, Wheaton.

Corbett, S. \& Fikkert, B., 2009, When helping hurts, Moody Publishers, Chicago.

Curtin, P., 1984, Cross-cultural trade in world history, Cambridge University Press, Cambridge. http://dx.doi.org/10.1017/CBO9780511661198

De Wet, F.W. \& Kruger, F.P., 2013, 'Blessed are those that hunger and thirst for righteousness: Sharpening the ethical dimension of prophetic preaching in a context of corruption', Verbum et Ecclesia 34(1), Art. \#722, 29 pages. http:// dx.doi.org/10.4102/

Du Plessis, A.L. \& Breed, G., 2013, 'A possible solution for corruption in South Africa with the church as initiator: A practical theological approach', HTS Teologiese Studies/Theological Studies 69(2), Art. \#1298, 10 pages. http://dx.doi. org/10.4102/hts.v69i2.1298

Estifania, E., 2007, 'Challenges to the Philippine culture of corruption', in S. Bracking (ed.), Corruption and development, pp. 121-135, Palgrave Macmillan, New York.

Evans, R., 2009, 'View from the inside - Shining the light on corporate wrongdoing: The role of business journalism', in D. Zinnbauer, R. Dobson \& K. Despota (eds.) Global corruption report 2009, Corruption and the private sector, pp. 154-156, Transparency International, Cambridge University Press, Cambridge.

Fitzsimons, V., 2007, 'Economic models of corruption', in S. Bracking (ed.), Corruption and development, pp. 46-74, Palgrave Macmillan, New York. 
Folarin, G., 2010, 'Lk. 12:13-21 in the context of human corruption,' Asia Journal of Theology 24(2), 312-324.

Goldingay, J., 2008, Psalms, 3 vols., Baker Academic, Grand Rapids.

Gordon, S., Roberts, B., Struwig, J. \& Dumisa, S., 2012, 'Business unusual: Perceptions of corruption in South Africa', HSRC Review 10(2), 12-15.

Grenz, S., 2005, 'The social God and the relational self: Toward a Trinitarian theology of the imago Dei', in L. Metzger (ed.), Trinitarian soundings in Systematic Theology, pp. 87-100, T\&T Clark, Edinburgh.

Hayden, K., 2012, 'Persian Empire achievements', in Bright Hub Education, viewed 13 January 2012, from http://www.brighthubeducation.com/history-homeworkhelp/88772-persian-empire-achievements/

'Private sector corruption rife', news24, 29 March, 2010, viewed n.d., from http:// www.news24.com/SouthAfrica/News/Private-sector-corruption-rife-20100329

Heitink, G., 1999, Practical Theology, Eerdmans, Grand Rapids.

Hollands, G., 2007, Corruption in infrastructure delivery, Water, Engineering and Development Centre, Loughborough University, Leicestershire.

Howard, D., 1990, 'The case for kingship in Deuteronomy and the Former Prophets', Westminster Theological Journal 52(1), 101-115.

Jayakumar , C., 1999, 'Powerlessness of the poor: Toward an alternative kingdom of God based paradigm of response', PhD thesis, Fuller Theological Seminary.

Kretzmann, J. \& Mcknight, J., 1993, Building communities from the inside out, ACTA publications, Chicago. PMid:19426016

Lambsdorff, J., 2008, 'Macro-perspective and micro-insights into the scale of corruption: Focus on Business Corruption Perceptions Index 2008', in D. Zinnbauer, R. Dobson \& K. Despota (eds.), Global corruption report 2009, Corruption and the private sector, pp. 395-402, Transparency International, Cambridge University Press, Cambridge.

Loretz, O., 2002, 'Psalmstudien', Beihefte zur Zeitschrift fur die alttestamentliche Wissenschaft 309, 268-273.

Mathie, A. \& Cunningham, G., 2002, 'From clients to citizens: Asset-Based Community Development as a strategy for community-driven development', Cody International Institute, Occasional Paper Series, No. 4, Antigonish, Nova Scotia.

Moo, D., 1996, The Epistle to the Romans, NICNT, Eerdmans, Grand Rapids.

National Council for Voluntary Organizations (NCVO), 2013, Definitions of public service delivery, viewed 13 January 2012, from http://www.fundingcentral.org. uk/page. aspx?sp=6114

Nolland, J., 1993, 'The use and abuse of riches, Luke 16:1-31', in D. Hubbard, G. Barker \& R. Martin (eds.), Word Biblical Commentary Luke 9:21-18:34, pp. 792-827, Word, Dallas, Texas.

Osmer, R., 2008, Practical Theology: An introduction, Eerdmans, Grand Rapids.
Pandey, P., 2010, 'Service delivery and corruption in public services: How does history matter?', American Economic Journal, Applied Economics 2(3), 190-204. http:// dx.doi.org/10.1257/app.2.3.190

Ramphele, M., 2013a, 'Rekindling the South African dream', IOL News, viewed n.d., from http://www.iol.co.za/news/politics/mamphela-ramphele-s-full-speech-1.1472163\#. UXIPWEr7BSE

Ramphele, M., 2013b, 'Stop fearing ANC and authority' IOL News, viewed n.d., from http://www.iol.co.za/news/politics/ramphele-stop-fearing-anc-and-authority1506802\#.UYpptOr7BSE.

Rans, S. \& Altman, H., 2002, Asset-based strategies for faith communities, ACTA Publications, Chicago.

Riaño, J., 2008, 'Bribe Payers Index', in D. Zinnbauer, R. Dobson \& K. Despota (eds.) Global corruption report 2009, Corruption and the private sector, pp. 402-406, Transparency International, Cambridge University Press, Cambridge.

Smith, A., [1776] 2013, An inquiry into the nature and causes of the wealth of nations, Library Economic Liberty, viewed 26 June 2013, from http://www.econlib.org/ library/Smith/smWN1.html\#B.I,\%20Introduction $\% 20 \% 20$ and $\% 20$ Plan $\% 20 \% 20$ library/Smith/smW

South African Government, 2004, Prevention and Combating of Corrupt Activities Act - South Africa, 2003, Governmeng Gazette, vol. 446, viewed 13 January 2012, from http://www.info.gov.za/acts/2004/a12-04/a12-04a.pdf

Stek, J., 2008, 'Psalms', in K. Barker (ed.), Zondervan Study Bible, pp. 778-951, Zondervan, Grand Rapids.

Stewart, D., Shamdasani, P. \& Rook, D., 2007, Focus groups: Theory and practice, SAGE Publications, London. (Research Methods Series, vol. 20)

Stiglitz, J., 2003, The roaring nineties, Norton, New York.

Tanzi, V., 1998, 'Corruption around the world: Causes, consequence, scope and cures,' IMF Staff Papers 45(4), 1-39 http://dx.doi.org/10.2307/3867585

Tate, M., 1990, Psalms 51-100, J. Watts (ed.), Word, Dallas, Texas. (Word Biblical Commentary, vol. 20).

Van Groningen, J., 2007, 'An introduction to Asset Based Community Development for church leaders', in Christian Reformed World Relief Committee, viewed 16 January 2013, from http://www.urbanministry.org/files/Introduction_To_ABCD Church_\%20Leaders_FINAL.pdf.

Vorster, J., 2012, 'Managing corruption in South Africa: The ethical responsibility of churches', Scriptura 109, 133-147.

Welsh, F., 2000, A history of South Africa, HarperCollins, London.

'Whistle blows for start of anti-corruption week', West Cape News, 29 January, 2013, viewed n.d., from http://westcapenews.com/?p=3286

Zausmer, R. \& Hawtin, D., 2012, 'Rooting out corruption in the service delivery sector - lessons for Egypt', in Global Partners and Associates, viewed n.d, from http:// www.global-partners.co.uk/?publications=corruption-in-egypt 